\title{
Nota dos editores - Edições Ano IX, Números 17, 18 e 19, publicadas no ano de 2020.
}

\section{(2) OpenEdition \\ Journals}

Electronic version

URL: http://journals.openedition.org/espacoeconomia/17247

DOI: 10.4000/espacoeconomia. 17247

ISSN: 2317-7837

Publisher

Núcleo de Pesquisa Espaço \& Economia

\section{Electronic reference}

"Nota dos editores - Edições Ano IX, Números 17, 18 e 19, publicadas no ano de 2020. », Espaço e Economia [Online], 19 | 2020, Online since 03 September 2020, connection on 24 September 2020. URL : http://journals.openedition.org/espacoeconomia/17247; DOI : https://doi.org/10.4000/ espacoeconomia. 17247

This text was automatically generated on 24 September 2020.

(c) NUPEE 


\section{Nota dos editores - Edições Ano IX, Números 17, 18 e 19, publicadas no ano de 2020.}

1 O conselho de editores da revista apresentará os agradecimentos e a relação de nomes dos pareceristas na última edição do ano, em novembro de 2020.

2 Cordialmente,

3 Floriano Godinho de Oliveira

4 Guilherme Ribeiro

5 Leandro Dias de Oliveira

6 Regina Tunes 